\begin{tabular}{|c|c|c|}
\hline $\begin{array}{l}\text { Vol. 511: 105-116, } 2014 \\
\text { doi: } 10.3354 / \text { meps } 10953\end{array}$ & $\begin{array}{c}\text { MARINE ECOLOGY PROGRESS SERIES } \\
\text { Mar Ecol Prog Ser }\end{array}$ & Published September 24 \\
\hline
\end{tabular}

\title{
Benthic Crustacea on coral reefs: a quantitative survey
}

\author{
M. J. Kramer ${ }^{1,2, *}$, D. R. Bellwood ${ }^{1,2}$, O. Bellwood ${ }^{1}$ \\ ${ }^{1}$ School of Marine and Tropical Biology, James Cook University, Townsville, QLD 4811, Australia \\ ${ }^{2}$ Australian Research Council Centre of Excellence for Coral Reef Studies, James Cook University, Townsville, QLD 4811, \\ Australia
}

\begin{abstract}
Benthic crustaceans are an important component of the coral reef fauna, yet our understanding of their ecological significance is incomplete. To determine the community structure, abundance, biomass and productivity of benthic Crustacea at Lizard Island, a mid-shelf reef on the Great Barrier Reef, Australia, we investigated 5 major microhabitats: dead coral, coral rubble, sand, epilithic algal matrix (EAM) and fine-branching live coral. Crustacean communities differed significantly among habitats, with the exception of dead coral and coral rubble. Dead coral was the most important microhabitat type in terms of crustacean abundance (7838 \pm 628 ind. $100 \mathrm{~cm}^{-2}$, mean $\left.\pm \mathrm{SE}\right)$, biomass $\left(0.75 \pm 0.13 \mathrm{~g} \mathrm{~m}^{-2}\right.$, wet weight $)$ and estimated productivity $(0.17 \pm$

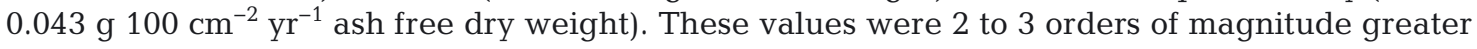
than those for the least important habitats (EAM and fine-branching live coral). Despite their abundance, the average crustacean body length was just $0.79 \pm 0.32 \mathrm{~mm}$, largely due to the dominance of harpacticoid copepods. In contrast, decapods exhibited very low abundances, but yielded the greatest biomass and productivity and were particularly abundant in dead coral and coral rubble. The results highlight the importance of small crustaceans and dead coral microhabitats as valuable contributors to the trophic structure of coral reefs.
\end{abstract}

KEY WORDS: Crustacea $\cdot$ Decapoda $\cdot$ Dead coral $\cdot$ Coral rubble $\cdot$ Biomass $\cdot$ Productivity

Resale or republication not permitted without written consent of the publisher

\section{INTRODUCTION}

Coral reefs are complex ecosystems that support a great abundance and high biomass of organisms (Ackerman \& Bellwood 2000, Stella et al. 2011, Enochs 2012). Motile invertebrates are particularly well represented, with an estimated 168000 species described on coral reefs (Ruppert et al. 2004, Stella et al. 2011), far surpassing the number of fish species ( 5000 species; Bellwood et al. 2012a). Despite their abundance and diversity, however, the great majority of coral reef invertebrates are easily overlooked, as they are either small or hide within the complex structure of the reef framework (Ginsburg 1983, Enochs 2012).

Crustaceans are one of the most speciose groups on coral reefs, comprising approximately $20 \%$ of all in- vertebrate species (Plaisance et al. 2011, Stella et al. 2011). Studies that have investigated coral reef crustaceans often examined the relatively conspicuous taxa found in live corals (e.g. Abele \& Patton 1976, Patton 1994, Stella et al. 2010) or those associated with fishes (Karplus 1987, Spotte 1998, Becker \& Grutter 2004). These crustaceans are almost exclusively members of the order Decapoda, which are often observed due to their relatively large size, bright colours and symbiotic relationships with fishes and corals. In addition, decapods are potentially important contributors to coral reef ecosystem health, performing roles such as defending live coral from predators (Pratchett 2001) or removing parasites from fishes (Becker \& Grutter 2004). Yet there are many other lesser-known crustacean taxa, such as Amphipoda, Cumacea, Cyclopoida, Harpacticoida, Isopoda, Ostracoda and Tanai- 
dacea, which also perform important ecological roles (Klumpp et al.1988, Preston \& Doherty 1994, Takada et al. 2008, Kramer et al. 2012). Their roles in the food chain and as major prey items are particularly well documented (Edgar \& Shaw 1995, Keable 1995, Glynn \& Enochs 2011, Kramer et al. 2013).

On coral reefs, crustaceans occur across all microhabitats (Ruppert et al. 2004). While decapods are known to associate with live corals (Abele \& Patton 1976, Patton 1994, Stella et al. 2011), other crustaceans are also a major faunal component of the invertebrate communities in dead coral (Klumpp et al. 1988, Preston \& Doherty 1994), coral rubble (Takada et al. 2008, Enochs \& Manzello 2012a), the epilithic algal matrix (EAM; Kramer et al. 2012) and sand (Jacoby \& Greenwood 1988, Danovaro \& Fraschetti 2002). Despite these studies, however, there has been no comprehensive overview or comparison of crustacean assemblages, abundance, or biomass among coral reef microhabitats.

Crustaceans have also been suggested to be important contributors to the productivity of reefs (Edgar et al. 1994, Cowles et al. 2009). Productivity appears to be a valuable, but often overlooked, aspect of a species' role in ecosystems (Edgar \& Moore 1986, Taylor 1998, Cowles et al. 2009). Estimates of productivity provide information on the relative importance of organisms as producers of organic matter for higher trophic levels (Taylor 1998). An assessment of productivity of crustaceans within various coral reef microhabitats will therefore provide a better understanding of the trophic value of Crustacea and the importance of various microhabitats in coral reef ecosystems. To date, there have been no among-habitat comparisons of crustacean productivity on coral reefs.

The overarching aim of the present study, therefore, is to provide a comprehensive overview of the community composition, abundance, biomass and productivity of crustaceans across 5 major benthic microhabitats (dead coral, coral rubble, sand, EAM and fine-branching live coral) on a mid-shelf coral reef of the Great Barrier Reef. The results of this study will be used to evaluate the trophic importance of crustaceans and their respective microhabitats in coral reef processes.

\section{MATERIALS AND METHODS}

\section{Study location}

Samples were collected in February 2013 from Lizard Island (1440' 40" S, $\left.145^{\circ} 26^{\prime} 55^{\prime \prime} \mathrm{E}\right)$, a mid-shelf island located in the northern Great Barrier Reef, Australia. Three sites were haphazardly selected at 2 semi-sheltered sampling locations (Mermaid Cove and Lagoon Entrance). The reef at each location was a typical fringing reef with a reef flat, crest and gentle slope that reached a sandy base at approximately $6 \mathrm{~m}$ water depth. The chosen microhabitats (which collectively covered $>80 \%$ of the substratum at the selected sites) consisted of dead coral, coral rubble, sand, EAM and fine-branching live coral. Before sampling, sites were inspected to ensure that all 5 microhabitats were present. Samples were collected from the crest region in an area that extended no more than $5 \mathrm{~m}$ onto the flat or down the slope. Within each site, 3 replicate samples from each microhabitat were collected from as close to the crest as possible, yielding a total of 18 samples of each of the 5 microhabitats (90 samples overall). All samples were fixed in $4 \%$ formaldehyde in seawater within $20 \mathrm{~min}$ of collection.

\section{Microhabitat description and sample collection}

Dead coral was defined as structurally intact branching coral skeletons devoid of live coral tissue but still attached to the main reef matrix. All dead coral samples were taken from Acropora sp. skeletons (predominantly $A$. nasuta or those of similar morphology). Dead coral protrusions with a visually estimated planar area of $\sim 100 \mathrm{~cm}^{2}$ (actual planar area: $68.0 \pm$ $1.8 \mathrm{~cm}^{2}$, mean $\pm \mathrm{SE}, \mathrm{n}=18$; measured using ImageJ; see detailed description in 'Laboratory processes') were surrounded by a plastic bag, removed using a hammer and chisel and placed into a sampling jar, taking care to minimise loss of organisms. All samples were of a similar volume $(127 \pm 5 \mathrm{ml}$ displacement volume, mean $\pm \mathrm{SE}, \mathrm{n}=18$ ) and complexity.

Coral rubble was defined as a loose accumulation of dead coral fragments. Due to the complex and uneven nature of coral rubble, sampling is inherently difficult. To overcome this problem, sampling was conducted by constructing wire baskets of $100 \mathrm{~cm}^{2}$ planar surface area and $5 \mathrm{~cm}$ depth, which held 203.7 $\pm 4.7 \mathrm{ml}$ (displacement volume, mean $\pm \mathrm{SE}, \mathrm{n}=18$ ) of coral rubble. The baskets were filled with coral rubble taken directly from a rubble field at each site and immediately placed into the depression from where the rubble was removed. Baskets were left at the site for $6 \mathrm{~d}$ to allow disturbed motile organisms to return to the coral rubble within the basket (following Takada et al. 2007). After this re-establishment period, the basket was carefully lifted and placed into a plastic bag in a manner that prevented loss of organisms. 
Sandy microhabitats were located at the base of the reef (5 $\mathrm{m}$ depth). Samples were collected by taking a $1 \mathrm{~cm}$ deep core with a $51 \mathrm{~mm}$ diameter corer, yielding $20.4 \mathrm{~cm}^{3}$ of sand. The core sample was transferred into a labelled plastic bag and fixed. A $1 \mathrm{~cm}$ depth incorporates most sediment infauna (Coull 1970) and samples the substratum most likely to be encountered by other reef organisms (e.g. fishes).

Samples of EAM were collected from exposed, horizontal areas of EAM (following Kramer et al. 2012). Using an underwater vacuum sampler, an area of $20.4 \mathrm{~cm}^{2}$ (defined by a plastic ring) was vacuumed for $30 \mathrm{~s}$. Material within the sampling area was drawn into the apparatus and retained by a $60 \mu \mathrm{m}$ filter mesh bag that was sealed underwater, placed into a labelled sample jar and fixed.

Fine-branching live coral was sampled following Stella et al. (2010). Acropora sp. (small corymbose form) was selected for sampling because of its abundance in the study area. Individual colonies of Acropora sp. were surrounded by a plastic bag to prevent resident fauna escaping, and were carefully chiseled off the reef. Colonies were then transported to a boat, removed from the bag and submerged into a bucket of freshwater for 1 min to extract all organisms. Care was taken to avoid immersing the dead coral (and the associated EAM) at the base of the colony. After $1 \mathrm{~min}$ in freshwater, the coral was removed and placed into a bucket of saltwater, where it was inspected for organisms that remained within the coral. The few individuals that were detected were removed and placed into the freshwater bucket. The contents of the freshwater bucket and the collection bag were filtered through a $60 \mu \mathrm{m}$ mesh bag and fixed. All sampled corals were of approximately the same height and planar area, to standardise for differences in the volume of the colony. Volumes were measured in the field using the displacement method, averaging $461 \pm 22 \mathrm{ml}$ (mean $\pm \mathrm{SE}, \mathrm{n}=18$ ) per sample. A photograph of the coral with a scale was taken to calculate the planar surface area using ImageJ $\left(242 \pm 10 \mathrm{~cm}^{2}\right.$, mean $\left.\pm \mathrm{SE}, \mathrm{n}=18\right)$.

\section{Benthic composition}

To measure the percentage benthic cover of each major microhabitat, photo-transects were conducted prior to sampling. A $20 \mathrm{~m}$ transect tape was laid along the reef profile (i.e. from slope to outer flat). At each $2 \mathrm{~m}$ interval along the tape, a $1 \times 1 \mathrm{~m}$ quadrat was placed over the reef and a photograph taken from above. Five replicate transects were conducted within each of the 3 sites selected for microhabitat sampling. Live coral was divided into 2 categories: fine-branching live coral (colonies with fine-scale complexity such as A. nasuta) and other coral (colonies with large-scale complexity, for example, massive Porites sp. and open branching A. formosa). The planar area of each microhabitat type was quantified from each image using ImageJ.

\section{Laboratory processes}

Dead coral and coral rubble samples were agitated within the sample jars to dislodge dead organisms from the coral skeleton. The coral skeleton was then removed from the jar and placed into a second empty vessel. The dislodged organisms in the original sample jar were poured through a $60 \mu \mathrm{m}$ filter and retained. This washing process was repeated 3 times (a pilot study revealed that 3 washes obtained over $98 \%$ of the organisms from the coral skeleton). Washed dead coral skeletons were then photographed with a scale to quantify the planar surface area using ImageJ (http://imagej.nih.gov/ij/index.html).

Samples that contained large numbers of organisms or inorganic matter (i.e. dead coral, coral rubble and sand) were subsampled using the Huntsman Marine Laboratory beaker technique (van Guelpen et al. 1982). Samples were stained with eosin erythrosin and washed onto a petri dish for investigation under $40 \times$ magnification. A grid on the base of the petri dish was followed, to avoid counting the same organism twice. Organisms were identified to the lowest practical taxonomic level (usually Order) and counted. Because of the potential loss of very small individuals $(<60 \mu \mathrm{m})$ from some habitats, copepod nauplii were not included in the analysis.

\section{Data analysis}

\section{Abundances}

Data from all microhabitats were standardised to $100 \mathrm{~cm}^{2}$ before analysis. A total of 15 taxonomic units were used, 8 of which were Crustacea (Amphipoda, Cumacea, Cyclopoida, Decapoda, Harpacticoida, Isopoda, Ostracoda and Tanaidacea; details in Table S1 in the Supplement at www.int-res.com/articles/suppl/ m511p105_supp.pdf). Differences in community structure among microhabitats were investigated using a non-metric multidimensional scaling (nMDS) analysis of proportional data on a Manhattan distance 
matrix. The nMDS ordination and associated taxoncontribution plots were constructed using the R package vegan (Oksanen et al. 2013). A permutational multivariate analysis of variance (PERMANOVA) was conducted in Primer 6 to test for differences between location, site and microhabitat. Pairwise comparisons, using the PERMANOVA extension in Primer 6, were used to investigate differences in assemblages between specific microhabitats.

\section{Biomass}

Wet-weight biomass of the various taxonomic groups was calculated by estimating the volumes of the first 100 organisms observed of each major crustacean taxon (Amphipoda, Cumacea, Cyclopoida, Decapoda, Harpacticoida, Isopoda, Ostracoda and Tanaidacea) following methods similar to those of Lawrence et al. (1987), who validated this method for micro-Crustacea (Copepoda). Decapoda within dead coral, coral rubble and fine-branching live coral varied in size; thus, they were grouped into their respective microhabitats for biomass estimates (Table S2 in the Supplement at www.int-res.com/ articles/suppl/m511p105_supp.pdf). Volume estimates were based on the resemblance of the taxa to simple geometric shapes, i.e. a cylinder (Amphipoda, some Decapoda, Harpacticoida and Tanaidacea), a cone (Cumacea and Cyclopoida) or cuboid (some Decapoda, Isopoda and Ostracoda). Individuals were measured for length and width (cylinder and cone) or length, width and depth (box) in $25 \mu \mathrm{m}$ increments using an ocular micrometer. For decapod crabs, only the carapace was measured, assuming that the pereopods (which were often no longer attached) would supplement the areas of the hypothetical box that the carapace did not fill. Biomass per unit volume was estimated using the Harpacticoida, for which the volume to biomass relationship is known (Kramer et al. 2012), as a standard. To calculate the mean abundance, biomass and productivity of crustaceans within a square metre of an average semi-sheltered reef, the respective values for each crustacean taxon within each of the 5 microhabitats was multiplied by the mean $( \pm 95 \% \mathrm{CI})$ proportional coverage of the respective microhabitat and summed.

\section{Productivity}

Productivity of the 5 microhabitats was estimated based on the general allometric equation of Edgar
(1990), following McLeod et al. (2014), where $P=$ $0.0049 \times B^{0.80} \times T^{0.89}$, such that $P$ is productivity $\left(\mu \mathrm{g}\right.$ ash-free dry weight [AFDW] $\left.\mathrm{m}^{-2} \mathrm{~d}^{-1}\right), B$ is the biomass of organisms within the microhabitat ( $\mu \mathrm{g}$ AFDW $\mathrm{m}^{-2}$ ) and $T$ is water temperature $\left({ }^{\circ} \mathrm{C}\right.$ ). Wet-weight biomass estimates were converted to AFDW using published conversion factors (Ricciardi \& Bourget 1998). Lizard Island Research Station sensors measured water temperature at the time of collection.

\section{RESULTS}

\section{Community composition}

The PERMANOVA comparing the cryptofaunal assemblages found no significant differences between the factors location or site; therefore, data were pooled for the remainder of the analyses. However, there was a significant difference among microhabitats $(\mathrm{p}<0.001)$ (Fig. S1 in the Supplement). To account for the marked difference between finebranching live coral and the remaining microhabitats, a second analysis was conducted, excluding fine-branching live coral. After the removal of finebranching live coral, the significant microhabitat effect remained ( $p<0.001)$ (Fig. S2 in the Supplement). The pairwise comparisons found no significant difference between the cryptofaunal assemblages in dead coral and coral rubble. All other pairwise comparisons were significantly different $(p<0.01)$ (Fig. S2)

Although other invertebrates such as Polychaeta and Gastropoda were recorded and included in initial data analyses (see Figs. S1 \& S2), groupings of microhabitats within ordination space were largely driven by crustacean taxa, and the statistical tests based on all invertebrates were very similar to those based just on crustacean assemblages (Figs. S1-S3 in the Supplement).

The relative contributions of each crustacean taxon to microhabitat ordinations indicated that decapods were strongly correlated with finebranching live coral (Fig. S3), whereas harpacticoid copepods were correlated with EAM microhabitats (Fig. 1). Sand microhabitats displayed assemblages dominanted by the Harpacticoida and, to some extent, Ostracoda and Cumacea (Fig. 1). Dead coral and coral rubble were characterised by numerous crustacean taxa, including Amphipoda, Cumacea, Decapoda, Isopoda and Tanaidacea (Fig. 1). 


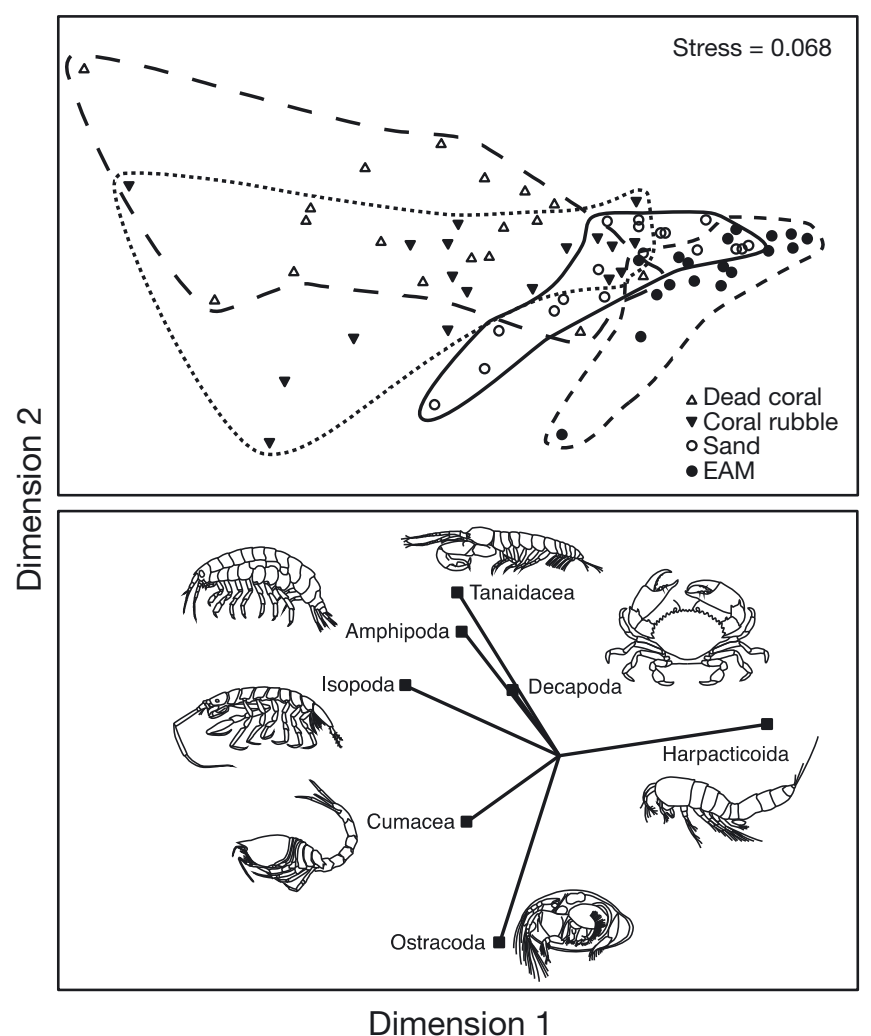

Fig. 1. Crustacean assemblages among microhabitats, excluding fine-branching live coral. (a) Non-metric multidimensional scaling of the abundance of crustacean taxa from dead coral, rubble, sand and epilithic algal matrix (EAM) habitats. (b) The relative contribution of each taxon to the variation in habitat groupings is represented by the vector points. Points indicate the direction of change and strength (correlation) of taxa to each habitat. Cyclopoida is not represented as it was not significantly correlated with any microhabitat $(\mathrm{p}>0.05)$

\section{Crustacean abundance, biomass and productivity across microhabitats}

Dead coral yielded the greatest numbers of crustaceans $\left(7838 \pm 662\right.$ ind. $100 \mathrm{~cm}^{-2}$, mean $\left.\pm \mathrm{SE}\right)$, closely followed by coral rubble $(6797 \pm 448$ ind. $100 \mathrm{~cm}^{-2}$ ) (Fig. 2a). In stark contrast, fine-branching live coral contained 3 orders of magnitude fewer Crustacea than dead coral, with just $6 \pm 1$ ind. $100 \mathrm{~cm}^{-2}$ (Fig. 2a). It is interesting to note, however, that these abundances were dominated by small harpacticoid copepods.

Biomass estimates may give a clearer view of the relative importance of the various microhabitats. Dead coral supported the greatest estimated wetweight biomass of crustaceans (Fig. 2b). Noticeably, the total biomass of crustaceans in dead coral $(0.75 \pm$

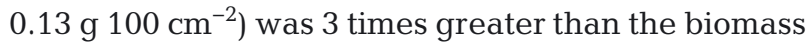
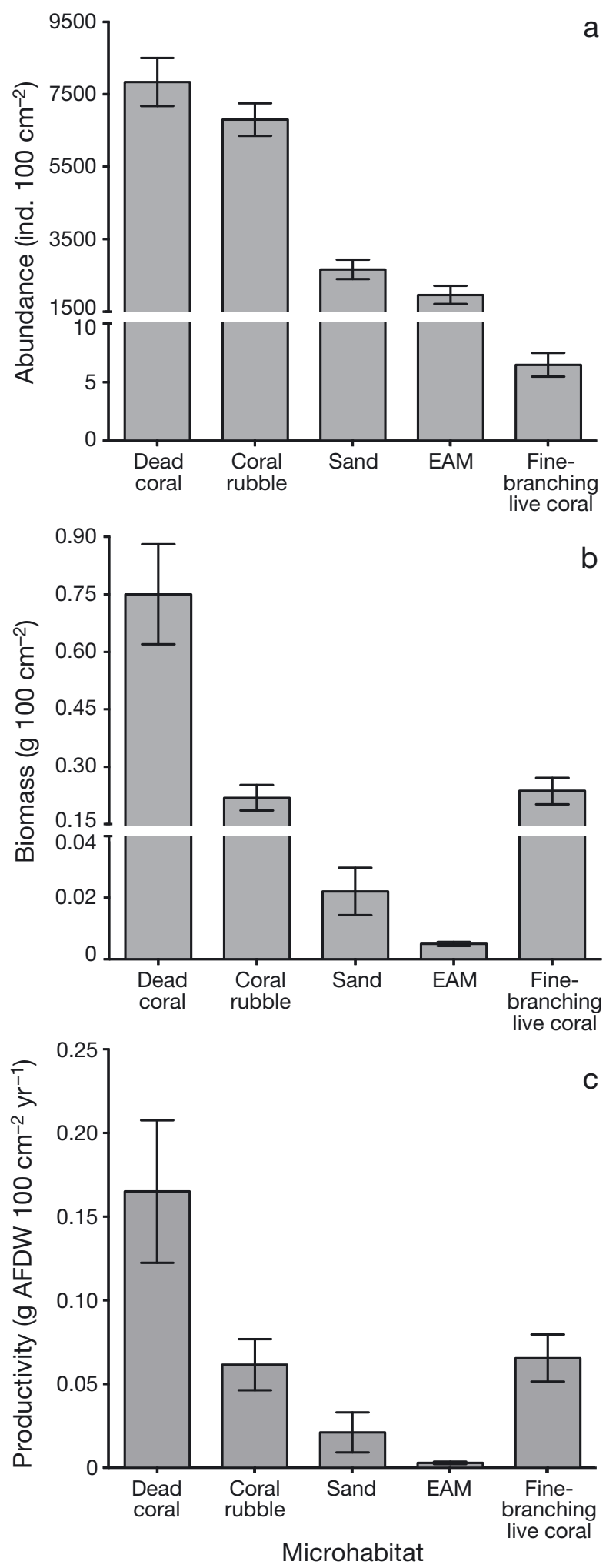

Fig. 2. Attributes of all Crustacea within a $100 \mathrm{~cm}^{2}$ (planar area) sample of each of the 5 microhabitats for (a) abundance, (b) estimated biomass ( $\mathrm{g}$ wet weight $100 \mathrm{~cm}^{-2}$ ) and (c) estimated productivity ( $\mathrm{g}$ ash-free dry weight [AFDW] $100 \mathrm{~cm}^{-2}$ $\left.\mathrm{yr}^{-1}\right)$. Data are means \pm SE. EAM: epilithic algal matrix 
in fine-branching live coral $\left(0.24 \pm 0.034{\left.\mathrm{~g} 100 \mathrm{~cm}^{-2}\right)}^{-2}\right.$ and 150 times greater than that in the EAM $(0.005 \pm$

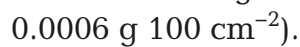

These patterns were mirrored in the productivity estimates. Dead coral was the most productive microhabitat, producing an estimated $0.17 \pm 0.043 \mathrm{~g}$ AFDW $100 \mathrm{~cm}^{-2} \mathrm{yr}^{-1}$, a value 55 times greater than the least productive microhabitat, the EAM $(0.003 \pm$ $0.0007 \mathrm{~g} \mathrm{AFDW} 100 \mathrm{~cm}^{-2} \mathrm{yr}^{-1}$ ) (Fig. 2c). Coral rubble and fine-branching live coral had similar productivity values $(0.062 \pm 0.015$ and $0.066 \pm 0.014 \mathrm{~g}$ AFDW $100 \mathrm{~cm}^{-2} \mathrm{yr}^{-1}$, respectively), whereas all other microhabitats (i.e. sand and the EAM) displayed values $<0.022 \mathrm{~g}$ AFDW $100 \mathrm{~cm}^{-2} \mathrm{yr}^{-1}$ (Fig. 2c).

\section{Crustacea at a reef-site scale}

Benthic surveys revealed that the greatest mean $( \pm 95 \%$ CI $)$ planar coverage of microhabitats in a square metre of reef was coral rubble $(0.34 \pm$ $\left.0.06 \mathrm{~m}^{2}\right)$, followed by EAM $\left(0.27 \pm 0.06 \mathrm{~m}^{2}\right)$, other coral $\left(0.19 \pm 0.03 \mathrm{~m}^{2}\right)$, fine-branching live coral $(0.10$ $\left.\pm 0.02 \mathrm{~m}^{2}\right)$, dead coral $\left(0.06 \pm 0.01 \mathrm{~m}^{2}\right)$, sand $(0.03 \pm$ $0.01 \mathrm{~m}^{2}$ ) and other microhabitats such as sponges and giant clams $\left(0.008 \pm 0.003 \mathrm{~m}^{-2}\right)$ (Fig. $\mathrm{S} 4$ in the Supplement). Using these data we can estimate the ecological values of each major taxon within an average square metre of Lizard Island semi-sheltered fringing reef (Fig. 3).

Based on an average square metre of the study reef, coral rubble was the most important microhabitat in terms of crustacean abundance, yielding $>3$ orders of magnitude more crustacean abundance than fine-branching live coral (coral rubble: 230248 \pm 43114 ind $\mathrm{m}^{-2}$; fine-branching live coral: $66 \pm$ 18 ind. $\mathrm{m}^{-2}$ ) (Fig. 3a). The biomass of crustaceans in coral rubble was higher than that in fine-branching live coral or dead coral (fine-branching live coral: 2.4 $\pm 0.6 \mathrm{~g} \mathrm{~m}^{-2}$; dead coral: $4.4 \pm 1.2 \mathrm{~g} \mathrm{~m}^{-2}$; coral rubble: $7.4 \pm 1.7 \mathrm{~g} \mathrm{~m}^{-2}$ ) (Fig. 3b), which was in part due to the prevalence of coral rubble $\left(0.34 \pm 0.06 \mathrm{~m}^{2}\right.$ planar surface area). Although dead coral was one of the least abundant microhabitats in the study area $(0.06 \pm$ $0.01 \mathrm{~m}^{2}$ planar surface area), it still supported almost twice the biomass compared to fine-branching live coral $\left(0.10 \pm 0.02 \mathrm{~m}^{2}\right.$ planar surface area). In contrast, despite their areas, sand $\left(0.03 \pm 0.01 \mathrm{~m}^{2}\right.$ planar surface area) and the EAM $\left(0.27 \pm 0.06 \mathrm{~m}^{2}\right.$ planar surface area) supported low biomass, with just $0.07 \pm$ 0.04 and $0.14 \pm 0.03 \mathrm{~g} \mathrm{~m}^{-2}$, respectively (Fig. 3c) over 50 times less than coral rubble or dead coral. Dead coral, coral rubble and branching coral consti-
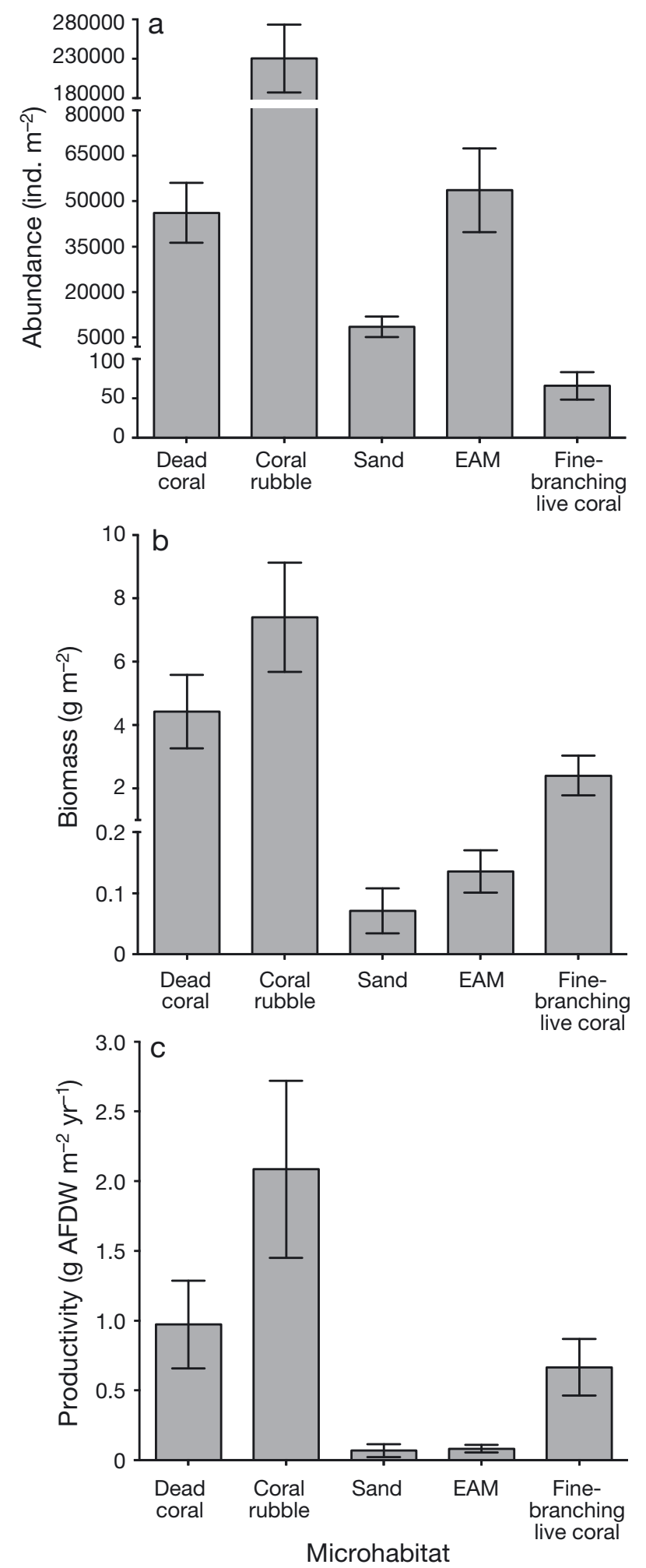

Fig. 3. Attributes of all Crustacea within 5 major microhabitats (based on the mean planar coverage of each microhabitat) within an average square metre of the study reef for (a) abundance, (b) estimated biomass ( $g$ wet weight $\mathrm{m}^{-2}$ ) and (c) estimated productivity ( $g$ ash-free dry weight [AFDW] $\mathrm{m}^{-2} \mathrm{yr}^{-1}$ ). Data are means \pm SE. EAM: epilithic algal matrix 
tuted a mean of $50 \%$ of the planar surface area of the study reef, yet supported $98 \%$ of the biomass of Crustacea.

Productivity of the microhabitats likewise revealed that coral rubble $(2.1 \pm 0.63 \mathrm{~g}$ AFDW $\mathrm{m}^{-2} \mathrm{yr}^{-1}$ ) was the most productive, showing a higher productivity than dead coral $(0.97 \pm$ $0.3 \mathrm{~g} \mathrm{AFDW} \mathrm{m}^{-2} \mathrm{yr}^{-1}$ ), fine-branching live coral $\left(0.7 \pm 0.2 \mathrm{~g} \mathrm{AFDW} \mathrm{m}^{-2} \mathrm{yr}^{-1}\right)$ and the EAM $(0.08$ $\pm 0.03 \mathrm{~g} \mathrm{AFDW} \mathrm{m}^{-2} \mathrm{yr}^{-1}$ ) (Fig. 3c). Despite its prevalence, the EAM contributed little to biomass and little to productivity.

\section{Taxonomic contribution of Crustacea on reefs}

Harpacticoida were, by far, the most abundant taxon on an average square metre of the study reef $\left(293465 \pm 40850\right.$ ind. $\left.\mathrm{m}^{-2}\right)$, being 7 times more abundant than all other taxa combined (Fig. 4a). Decapoda, by comparison, had a mean abundance of just $382 \pm 76$ ind. $\mathrm{m}^{-2}$ (Fig. 4a). Despite their very low abundance, Decapoda had the greatest biomass (12.5 \pm $2.0 \mathrm{~g} \mathrm{~m}^{-2}$ ), 18 times greater than that of the Harpacticoida $\left(0.7 \pm 0.1 \mathrm{~g} \mathrm{~m}^{-2}\right)$ (Fig. $\left.4 \mathrm{~b}\right)$. The estimated productivity of each taxon revealed similar patterns, with Decapoda being the most productive $\left(3.9 \pm 0.9 \mathrm{~g} \mathrm{AFDW} \mathrm{m}^{-2} \mathrm{yr}^{-1}\right)$ and Cyclopoida being the least productive $(0.005 \pm$ $0.001 \mathrm{~g} \mathrm{AFDW} \mathrm{m}^{-2} \mathrm{yr}^{-1}$ ) (Fig. 4c).

\section{DISCUSSION}

Although invertebrate assemblages within specific coral reef microhabitats have been described in a number of studies (Takada et al. 2008, Plaisance et al. 2009, Stella et al. 2011, Kramer et al. 2012), investigations that compare faunas among microhabitats are rare (but see Enochs 2012). The present study, therefore, examined the assemblages, abundance, estimated biomass and estimated productivity of crustaceans within 5 major microhabitats on a coral reef. Differences between microhabitats were distinct, with dead coral and coral rubble yielding by far the greatest abundance, biomass and productivity of crustaceans. In contrast, fine-branching live coral sheltered very few crustaceans. As these individuals tended to be large, the crustacean biomass in finebranching live coral was still comparable to
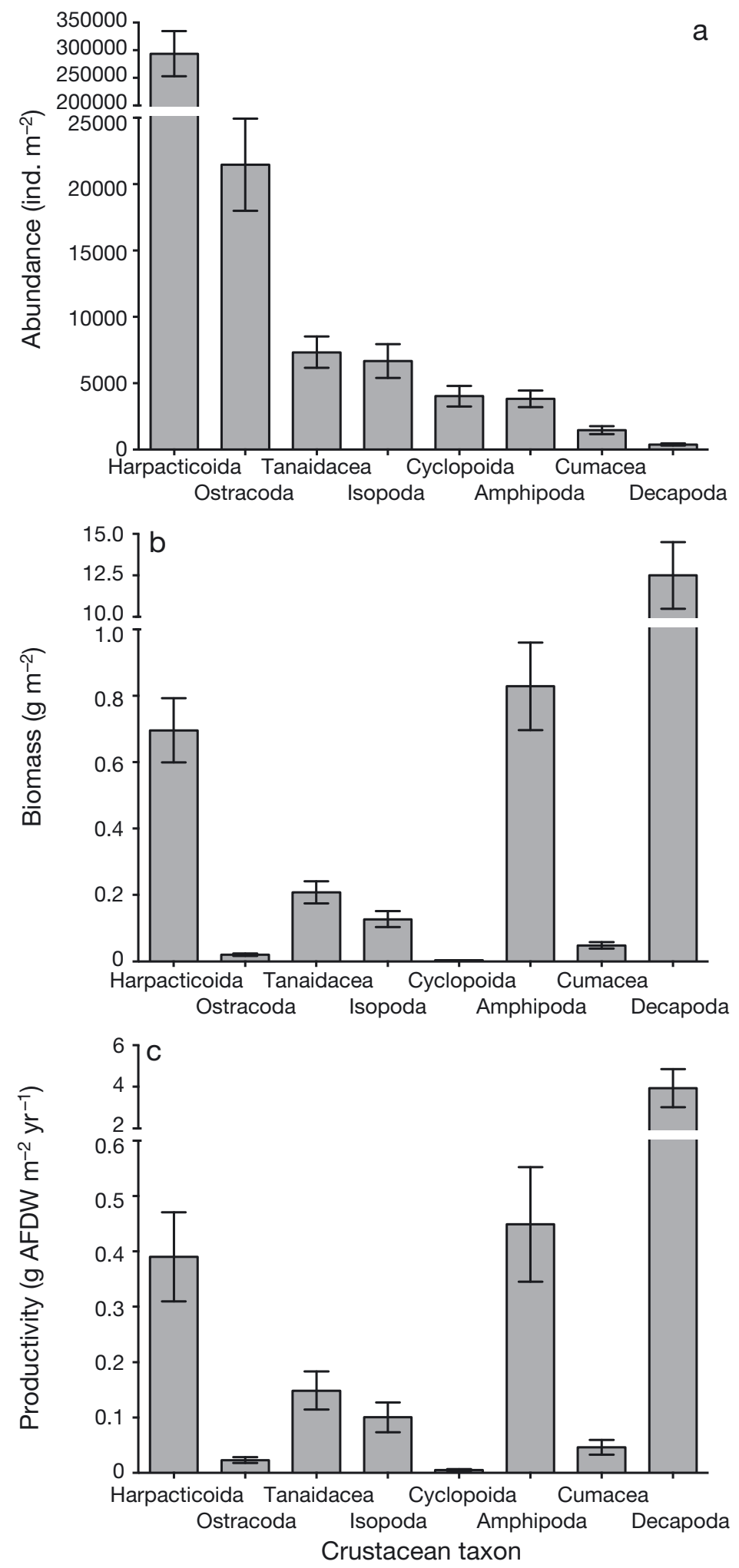

Fig. 4. Taxonomic contribution of Crustacea taxa within a typical square metre of coral reef (values are scaled to the planar area coverage of each microhabitat) for (a) abundance, (b) estimated biomass ( $\mathrm{g}$ wet weight $\mathrm{m}^{-2}$ ) and (c) estimated productivity ( $\mathrm{g}$ ash-free dry weight $\left[\right.$ AFDW] $\mathrm{m}^{-2} \mathrm{yr}^{-1}$ ). Data are means \pm SE. EAM: epilithic algal matrix 
that found in dead coral or coral rubble. Live coral cover is often considered the most important unit of measure in determining coral reef health (Goatley \& Bellwood 2011, Vroom 2011) as it is an important microhabitat for the recruitment of juvenile fishes (Jones et al. 2004), the preferred microhabitat for specific fishes and crustaceans (Bellwood et al. 2012b, Stella et al. 2010) and the foundation of coral reef structural complexity (Graham et al. 2006). However, our results suggest that the most valuable microhabitats on a coral reef, in terms of supporting the biomass and productivity of trophically valuable crustaceans, are dead coral and coral rubble. Each microhabitat on a coral reef, therefore, must be present in appropriate proportions to maintain a diverse, healthy ecosystem.

\section{Dead coral, coral rubble and the EAM}

Dead coral was a particularly important microhabitat for crustaceans, with approximately 3 orders of magnitude more individuals and 3 times more biomass than fine-branching live coral per unit area. The greater abundance and biomass of all crustaceans in dead coral is probably due to the combination of high structural complexity (Enochs et al. 2011, Enochs 2012), increased surface area of the associated EAM (Preston \& Doherty 1994), and the diversity of 'nano-habitats' (i.e. filamentous algae, macroalgae, crustose coralline algae and sponges; Ginsburg 1983, Klumpp et al. 1988, Glynn \& Enochs 2011) providing both shelter and trophic resources (i.e. algae, microalgae and detritus). However, dead coral was a relatively uncommon microhabitat on the reef, comprising only $5.9 \pm 1.2 \%$ of the planar area. The lack of dead coral may be attributed to 3 factors. Firstly, some dead coral microhabitats may have been concealed under a canopy of live coral, particularly branching taxa, and, thus, may be under-represented in the benthic surveys (Goatley \& Bellwood 2011). Indeed, for some species of branching coral, live tissue may only cover the outermost $20-80 \%$ of the branches, obscuring the dead coral skeleton that contains a diverse, abundant and different crustacean community (McCloskey 1970, Lewis \& Snelgrove 1990). Secondly, bioerosion by boring organisms and parrotfishes slowly removes the skeletal structure after the death of a coral colony (Kiene \& Hutchings 1994, Bellwood et al. 2003). Alternatively, physical forces may break off the dead coral, with the eroded fragments accumulating as coral rubble (Hughes 1994, Rasser \& Riegl 2002).
Since dead coral is often transformed into coral rubble, these 2 microhabitats have similar structure and resource attributes. As a result, the crustacean assemblages of dead coral and coral rubble remain very similar. Likewise, the abundance and biomass of crustaceans have broadly comparable values between the 2 microhabitats. Although coral rubble has slightly fewer individuals, the main difference is in the biomass, with rubble having only a third of the crustacean biomass of dead coral. This decrease is probably due to the reduced complexity in coral rubble, with fragments supporting fewer large cryptic species (Enochs et al. 2011). A similar effect has been observed in live corals, with less complex growth forms supporting low crustacean abundance and biomass (Vytopil \& Willis 2001, Stella et al. 2010). In contrast, dead microhabitats with low environmental water flow and low porosity have been found to support higher abundance and biomass of cryptofauna than habitats with high water flow and high porosity (Enochs et al. 2011). In this context, dead coral may be considered to be of a lower porosity (i.e. smaller spaces between branches) and slightly higher water flow than coral rubble due to minimal erosion and its upright position on the reef. As such, complexity, porosity and water flow are likely to be important factors that support high abundance and biomass in dead coral.

Coral rubble covers 5.8 times the area covered by dead coral on the surveyed reefs. In terms of overall contribution to reef crustacean abundances and biomass, therefore, coral rubble may be a more important microhabitat than dead coral. The value of coral rubble has also been identified in the Pacific Gulf of Panama, where cryptofaunal biomass (i.e. all invertebrates $>2 \mathrm{~mm}$ ) in coral rubble was estimated to be 3.5 $\pm 1.1 \mathrm{~g} \mathrm{AFDW} \mathrm{m}^{-2}$ (Enochs 2012). In comparison, the present study on the Great Barrier Reef (GBR) found that, in coral rubble, crustaceans alone yielded $3.5 \pm$ $0.54 \mathrm{~g} \mathrm{AFDW} \mathrm{m}^{-2}$ (converted using factors from Ricciardi \& Bourget 1998). If crustaceans contribute approximately a third of the cryptofaunal biomass in dead substrates (Enochs 2012), this suggests that the total invertebrate biomass within a GBR coral rubble microhabitat is 3 times greater than that on eastern Pacific Panama reefs. These differences are probably due to variation in factors such as primary productivity (Hatcher 1990, Klumpp \& McKinnon 1992), nutrient profiles (Fabricius 2005, Pascal et al. 2013) and, most importantly, coral species, as rubble morphology and complexity are likely to strongly influence the cryptofaunal populations at each location (Vytopil \& Willis 2001, Takada et al. 2007, Enochs \& Manzello 2012a). 
The EAM is a ubiquitous and abundant microhabitat that is found across all dead substrates (Goatley \& Bellwood 2011, Connell et al. 2014). Therefore, it is intuitive that the EAM crustacean assemblage should be a prominent component of all microhabitats in the present study, excluding live coral and sand. Indeed, the dominant EAM crustaceans, Harpacticoida, were the most abundant taxon across all microhabitats, particularly in dead coral and coral rubble. The high structural complexity of these 2 microhabitats presents a relatively extensive surface area that is colonised by a variety of algal and encrusting taxa, which, in turn, supports the benthic microalgae, protozoans and detrital resources on which harpacticoids feed (Buffan-Dubau et al. 1996, Buffan-Dubau \& Carman 2000). The slight overlap of the nMDS groupings for dead coral, coral rubble, sand and EAM is likely due to the abundance of harpacticoid copepods in each microhabitat. It is interesting to note that harpacticoids have similar densities in EAM and sand microhabitats. Although the structures of sand and the EAM are not as complex as those of dead coral or coral rubble at larger scales, it is likely that sufficient microphytal resources exist in sand and the EAM at a microscale to support populations of these very small crustaceans (Montagna et al. 1995, Miller et al. 1996).

\section{Comparison with other marine taxa and environments}

Although the present study has identified crustaceans as highly abundant reef organisms across a variety of microhabitats, it is difficult to visually appreciate Crustacea, as many individuals are either very small or cryptic. In comparison, fishes are often conspicuous and can be quantified using relatively rapid visual censuses and ichthyocide sampling methods. The data in the present study allow the crustacean community to be compared with a representative fish assemblage from a similar habitat in the same location: Lizard Island, GBR, Australia (cf. Depczynski et al. 2007, Enochs 2012). In this comparison, the abundance of crustaceans on coral reefs is approximately 4 orders of magnitude greater than that of fishes (338 672 and 20 ind. $\mathrm{m}^{-2}$, respectively). In contrast, the wet-weight biomass of fishes $(158.0 \mathrm{~g}$ $\mathrm{m}^{-2}$; Depczynski et al. 2007) is approximately 1 order of magnitude greater than that of crustaceans $(14.4 \mathrm{~g}$ $\mathrm{m}^{-2}$; present study). Thus, even though crustaceans on coral reefs are generally very small organisms (mean $\pm \mathrm{SE}$; body length $=0.79 \pm 0.32 \mathrm{~mm}$ and mass
$=7.62 \pm 7.59 \mathrm{mg}$ for all crustacean taxa), their very high abundance results in a biomass value that approaches the same order of magnitude as that of fishes. Furthermore, the present study did not include very large decapods such as crabs (i.e. Portunidae and Xanthidae) or lobsters (i.e. Palinuridae). These large crustaceans were not observed at the sampling locations because they shelter deep within the reef structure and only emerge at night (Frisch 2007). Inclusion of these larger crustaceans would increase the estimated biomass of crustaceans on coral reefs and further decrease the difference between fishes and Crustacea.

The values above are based on standing stocks. The productivity of Crustacea is, perhaps, a more important metric as it provides information on the ability of this group of organisms to transfer energy to higher trophic levels (cf. Depczynski et al. 2007). Indeed, the estimated productivity of crustaceans $\left(0.066 \mathrm{~g}\right.$ wet weight $\left.\mathrm{m}^{-2} \mathrm{~d}^{-1}\right)$ is only 3 times less than the estimated productivity of fishes $(0.20 \mathrm{~g}$ wet weight $\mathrm{m}^{-2} \mathrm{~d}^{-1}$; Depczynski et al. 2007). Considering that many fishes feed on crustaceans (Hobson 1974, Edgar \& Shaw 1995, Randall et al. 1997), it is suggested that Crustacea are a major trophodynamic component of coral reefs, providing an important link in the dominant microbial- and detrital-based food webs (Arias-González et al. 1997, Depczynski et al. 2007). In contrast, productivity of coral reef microhabitats has rarely been studied, and then only with a focus on the primary productivity of the EAM (Hatcher 1990, Klumpp \& McKinnon 1992, Russ 2003) and secondary production in lagoonal soft sediments (Riddle et al. 1990, Carleton \& McKinnon 2007). In the present study, crustaceans in dead coral are similar in productivity (16.5 g AFDW $\mathrm{m}^{-2} \mathrm{yr}^{-1}$ ) to the productivity of organisms in GBR lagoonal sediments on a mid-shelf reef (19.0 g AFDW m ${ }^{-2} \mathrm{yr}^{-1}$; Riddle et al. 1990). However, the present study only addressed the productivity of crustaceans. The productivity of the complete faunal assemblage of each microhabitat, however, is likely to be up to 9 times greater than the values based on crustaceans alone (cf. Riddle et al. 1990). If this is the case, the most productive microhabitat, dead coral, may be estimated to produce up to $149 \mathrm{~g}$ AFDW $\mathrm{m}^{-2} \mathrm{yr}^{-1}$. This value would suggest that dead coral may be one of the most productive microhabitats in the world, only being surpassed by Californian macrophyte detritus ( 7000 $\mathrm{g}$ AFDW m $\mathrm{m}^{-2} \mathrm{yr}^{-1}$; Vetter 1995, Taylor 1998) and mussel beds in the Wadden Sea (468 g AFDW m $\mathrm{yr}^{-1}$; Asmus 1987, Taylor 1998). 
These comparisons are interesting in light of Darwin's paradox, which questions how coral reefs can be so productive in oligotrophic tropical oceans (Sammarco et al. 1999). The abundance and high productivity of crustaceans are likely to be a contributing factor, as these organisms are capable of rapidly consuming and incorporating the available primary productivity into the trophic structure of the ecosystem (Taylor 1998). Thus, the lower levels of a coral reef's trophic structure may form more of an inverse pyramid, where the biomass of consumers is greater than that of the primary producers due to rapid consumption and recycling of easily assimilated and nutritionally valuable resources (Shurin et al. 2006, Cebrian et al. 2009). This may apply at both primary and secondary consumer levels, with crustaceans rapidly assimilating primary productivity and, with their high productivity, likewise supporting a high biomass of secondary consumers (i.e. fishes).

Crustaceans are an important component of all benthic coral reef microhabitats. Although abundances, biomass and productivity differed considerably among microhabitats, dead coral and coral rubble were the most important for all of these measures. The contribution of Crustacea within dead coral and coral rubble to the trophic structure of a coral reef is substantial, acting as consumers of algal and detrital material (Klumpp et al. 1988, Preston \& Doherty 1994) and providing a resource to a wide variety of predatory invertebrates and fishes (Randall et al. 1997 Bellwood et al. 2006, Kramer et al. 2013).

Coral reefs worldwide are currently experiencing a variety of environmental and anthropogenic stressors that are modifying the structure of benthic reef communities (Hughes et al. 2003, Knowlton \& Jackson 2008). One of the most apparent consequences is the loss of both corals and 3-dimensional structure (Graham et al. 2007, Pratchett et al. 2008). In both cases this is very likely to have a direct detrimental effect on crustacean communities, particularly for larger taxa. By understanding how different microhabitats contribute ecologically to marine ecosystems, predictions can be made in terms of the future implications of habitat degradation and climate change on reef Crustacea (cf. Enochs \& Manzello 2012b). Whilst fine-branching live coral is an important habitat, especially for relatively large decapods, its main contribution - from a crustacean perspective - may be after the coral's death. Dead coral and coral rubble are highly dependent on the growth of live coral to sustain the structural complexity that is required to support diverse invertebrate faunas. Although finebranching live coral may be relatively depauperate in crustacean fauna, it is an essential microhabitat that, upon death, supplies a coral reef with the necessary structure to support abundant and productive crustacean assemblages. Thus, the trophic complexity of a coral reef may not depend solely on maximising the coverage of live coral. Instead, it is the ongoing turnover of corals that produce dead substrata that are the key to supporting abundant and productive crustacean communities on coral reefs.

Acknowledgements. The authors thank C. E. Mirbach, S. J. Brandl and the staff of Lizard Island Research Station for field support, and S. J. Brandl and 4 anonymous reviewers for helpful comments. D.R.B. was supported by the Australian Research Council.

\section{LITERATURE CITED}

Abele LG, Patton WK (1976) The size of coral heads and the community biology of associated decapod crustaceans. J Biogeogr 3:35-47

Ackerman JL, Bellwood DR (2000) Reef fish assemblages: a re-evaluation using enclosed rotenone stations. Mar Ecol Prog Ser 206:227-237

Arias-González JE, Delesalle B, Salvat B, Galzin R (1997) Trophic functioning of the Tiahura reef sector, Moorea Island, French Polynesia. Coral Reefs 16:231-246

Asmus H (1987) Secondary production of an intertidal mussel bed community related to its storage and turnover compartments. Mar Ecol Prog Ser 39:251-266

> Becker JH, Grutter AS (2004) Cleaner shrimp do clean. Coral Reefs 23:515-520

Bellwood DR, Hoey AS, Choat JH (2003) Limited functional redundancy in high diversity systems: resilience and ecosystem function on coral reefs. Ecol Lett 6:281-285

Bellwood DR, Wainwright PC, Fulton CJ, Hoey AS (2006) Functional versatility supports coral reef biodiversity. Proc Biol Sci 273:101-107

Bellwood DR, Renema W, Rosen BR (2012a) Biodiversity hotspots, evolution and coral reef biogeography: a review. In: Gower DJ, Johnson K, Richardson J, Rosen BR, Rüber L, Williams S (eds) Biotic evolution and environmental change in Southeast Asia. Cambridge University Press, Cambridge, p 216-245

Bellwood DR, Baird AH, Depczynski M, González-Cabello A, Hoey AS, Lefèvre CD, Tanner JK (2012b) Coral recovery may not herald the return of fishes on damaged coral reefs. Oecologia 170:567-573

Buffan-Dubau E, Carman KR (2000) Diel feeding behavior of meiofauna and their relationships with microalgal resources. Limnol Oceanogr 45:381-395

Buffan-Dubau E, de Wit R, Castel J (1996) Feeding selectivity of the harpacticoid copepod Canuella perplexa in benthic muddy environments demonstrated by HPLC analyses of chlorin and carotenoid pigments. Mar Ecol Prog Ser 137:71-82

Carleton JH, McKinnon AD (2007) Resident mysids: secondary production, consumption, and trophic role in a coral reef lagoon. Mar Ecol Prog Ser 336:89-98

- Cebrian J, Shurin JB, Borer ET, Cardinale BJ, Ngai JT, Smith MD, Fagan WF (2009) Producer nutritional quality 
controls ecosystem trophic structure. PLoS ONE 4:e4929

Connell SD, Foster MS, Airoldi L (2014) What are algal turfs? Towards a better description of turfs. Mar Ecol Prog Ser 495:299-307

$>$ Coull B (1970) Shallow water meiobenthos of the Bermuda platform. Oecologia 4:325-357

$>$ Cowles A, Hewitt JE, Taylor RB (2009) Density, biomass and productivity of small mobile invertebrates in a wide range of coastal habitats. Mar Ecol Prog Ser 384:175-185

- Danovaro R, Fraschetti S (2002) Meiofaunal vertical zonation on hard-bottoms: comparison with soft-bottom meiofauna. Mar Ecol Prog Ser 230:159-169

Depczynski M, Fulton CJ, Marnane MJ, Bellwood DR (2007) Life history patterns shape energy allocation among fishes on coral reefs. Oecologia 153:111-120

Edgar GJ (1990) The use of the size structure of benthic macrofaunal communities to estimate faunal biomass and secondary production. J Exp Mar Biol Ecol 137: 195-214

Edgar GJ, Moore PG (1986) Macro-algae as habitats for motile macrofauna. Monogr Biol 4:255-277

Edgar GJ, Shaw C (1995) The production and trophic ecology of shallow-water fish assemblages in southern Australia. III. General relationships between sediments, seagrasses, invertebrates and fishes. J Exp Mar Biol Ecol 194:107-131

Edgar GJ, Shaw C, Watson GF, Hammond LS (1994) Comparisons of species richness, size-structure and production of benthos in vegetated and unvegetated habitats in Western Port, Victoria. J Exp Mar Biol Ecol 176:201-226

> Enochs IC (2012) Motile cryptofauna associated with live and dead coral substrates: implications for coral mortality and framework erosion. Mar Biol 159:709-722

Enochs IC, Manzello DP (2012a) Species richness of motile cryptofauna across a gradient of reef framework erosion. Coral Reefs 31:653-661

Enochs IC, Manzello DP (2012b) Responses of cryptofaunal species richness and trophic potential to coral reef habitat degradation. Diversity 4:94-104

Enochs IC, Toth LT, Brandtneris VW, Afflerbach JC, Manzello DP (2011) Environmental determinants of motile cryptofauna on an eastern Pacific coral reef. Mar Ecol Prog Ser 438:105-118

Fabricius KE (2005) Effects of terrestrial runoff on the ecology of corals and coral reefs: review and synthesis. Mar Pollut Bull 50:125-146

- Frisch AJ (2007) Short- and long-term movements of painted lobster (Panulirus versicolor) on a coral reef at Northwest Island, Australia. Coral Reefs 26:311-317

Ginsburg RN (1983) Geological and biological roles of cavities in coral reefs. In: Barnes D (ed) Perspectives on coral reefs. Brian Clouston Publisher, Townsville, p 148-153

Glynn PW, Enochs IC (2011) Invertebrates and their roles in coral reef ecosystems. In: Dubinsky Z, Stambler N (eds) Coral reefs: an ecosystem in transition. Springer, Dordrecht, p 273-325

Goatley CHR, Bellwood DR (2011) The roles of dimensionality, canopies and complexity in ecosystem monitoring. PLoS ONE 6:e27307

> Graham NAJ, Wilson SK, Simon J, Polunin NVC, Bijoux JP, Robinson J (2006) Dynamic fragility of oceanic coral reef ecosystems. Proc Natl Acad Sci USA 103:8425-8429

$>$ Graham NAJ, Wilson SK, Jennings S, Polunin NVC, Robinson J, Bijoux JP, Daw TM (2007) Lag effects in the impacts of mass coral bleaching on coral reef fish, fish- eries, and ecosystems. Conserv Biol 21:1291-1300

Hatcher BG (1990) Coral reef primary productivity. A hierarchy of pattern and process. Trends Ecol Evol 5:149-155

Hobson ES (1974) Feeding relationships of teleostean fishes on coral reefs in Kona, Hawaii. Fish Bull 72:915-1031

> Hughes TP (1994) Catastrophes, phase shifts, and largescale degradation of a Caribbean coral reef. Science 265: $1547-1551$

Hughes TP, Baird AH, Bellwood DR, Card M and others (2003) Climate change, human impacts, and the resilience of coral reefs. Science 301:929-933

> Jacoby CA, Greenwood JG (1988) Spatial, temporal and behavioural patterns in emergence of zooplankton in the lagoon of Heron Reef, Great Barrier Reef, Australia. Mar Biol 97:309-328

Jones GP, McCormick MI, Srinivasan M, Eagle JV, Paine RT (2004) Coral decline threatens fish biodiversity in marine reserves. Proc Natl Acad Sci USA 101:8251-8253

Karplus I (1987) The association between gobiid fishes and burrowing alpheid shrimps. Oceanogr Mar Biol Annu Rev 25:507-562

Keable SJ (1995) Structure of the marine invertebrate scavenging guild of a tropical reef ecosystem: field studies at Lizard Island, Queensland, Australia. J Nat Hist 29: $27-45$

Kiene WE, Hutchings PA (1994) Bioerosion experiments at Lizard Island, Great Barrier Reef. Coral Reefs 13:91-98

Klumpp DW, McKinnon AD (1992) Community structure, biomass and productivity of epilithic algal communities on the Great Barrier Reef: dynamics at different spatial scales. Mar Ecol Prog Ser 86:77-89

Klumpp DW, McKinnon AD, Mundy CN (1988) Motile cryptofauna of a coral reef-abundance, distribution and trophic potential. Mar Ecol Prog Ser 45:95-108

Knowlton N, Jackson JBC (2008) Shifting baselines, local impacts, and global change on coral reefs. PLoS Biol 6:e54

Kramer MJ, Bellwood DR, Bellwood O (2012) Cryptofauna of the epilithic algal matrix on an inshore coral reef, Great Barrier Reef. Coral Reefs 31:1007-1015

Kramer MJ, Bellwood O, Bellwood DR (2013) The trophic importance of algal turfs for coral reef fishes: the crustacean link. Coral Reefs 32:575-583

Lawrence SG, Malley DF, Findlay WJ, Maclver MA, Delbaere IL (1987) Method for estimating dry weight of freshwater planktonic crustaceans from measures of length and shape. Can J Fish Aquat Sci 44:s264-s274

Lewis JB, Snelgrove PVR (1990) Corallum morphology and composition of crustacean cryptofauna of the hermatypic coral Madracis mirabilis. Mar Biol 106:267-272

McCloskey LR (1970) The dynamics of the community associated with a marine scleractinian coral. Int Rev Gesamten Hydrobiol Hydrograph 55:13-81

McLeod IM, Parsons DM, Morrison MA, Van Dijken SG, Taylor RB (2014) Mussel reefs on soft sediments: a severely reduced but important habitat for macroinvertebrates and fishes in New Zealand. N Z J Mar Freshw Res 48:48-59

Miller DC, Geider RJ, MacIntyre HL (1996) Microphytobenthos: the ecological role of the 'secret garden' of unvegetated, shallow-water marine habitats. II. Role in sediment stability and shallow-water food webs. Estuaries 19:202-212

Montagna PA, Blanchard GF, Dinet A (1995) Effect of production and biomass of intertidal microphytobenthos on 
meiofaunal grazing rates. J Exp Mar Biol Ecol 185: 149-165

Oksanen J, Blanchet FG, Kindt R, Legendre P and others (2013) Vegan: community ecology package. R package Version 2.0-7. Available at: http://cran.r-project.org/ web/packages/vegan/index.html

Pascal PY, Fleeger JW, Boschker HTS, Mitwally HM, Johnson DS (2013) Response of the benthic food web to shortand long-term nutrient enrichment in saltmarsh mudflats. Mar Ecol Prog Ser 474:27-41

Patton WK (1994) Distribution and ecology of animals associated with branching corals (Acropora spp.) from the Great Barrier Reef, Australia. Bull Mar Sci 55:193-211

Plaisance L, Knowlton N, Paulay G, Meyer C (2009) Reefassociated crustacean fauna: biodiversity estimates using semi-quantitative sampling and DNA barcoding. Coral Reefs 28:977-986

Plaisance L, Caley MJ, Brainard RE, Knowlton N (2011) The diversity of coral reefs: What are we missing? PLoS ONE 6:e25026

Pratchett MS (2001) Influence of coral symbionts on feeding preferences of crown-of-thorns starfish Acanthaster planci in the western Pacific. Mar Ecol Prog Ser 214: 111-119

Pratchett MS, Munday PL, Wilson SK, Graham NAJ and others (2008) Effects of climate-induced coral bleaching on coral-reef fishes - Ecological and economic consequences. Oceanogr Mar Biol Annu Rev 46:251-296

Preston NP, Doherty PJ (1994) Cross-shelf patterns in the community structure of coral-dwelling Crustacea in the central region of the Great Barrier Reef. II. Cryptofauna. Mar Ecol Prog Ser 104:27-38

Randall J, Allen G, Steene R (1997) Fishes of the Great Barrier Reef and Coral Sea. University of Hawaii Press, Honolulu, HI

Rasser M, Riegl B (2002) Holocene coral reef rubble and its binding agents. Coral Reefs 21:57-72

Ricciardi A, Bourget E (1998) Weight-to-weight conversion factors for marine benthic macroinvertebrates. Mar Ecol Prog Ser 163:245-251

Riddle MJ, Alongi DM, Dayton PK, Hansen JA, Klumpp DW (1990) Detrital pathways in a coral reef lagoon. I. Macrofaunal biomass and estimates of production. Mar Biol 104:109-118

Ruppert EE, Fox RS, Barnes RD (2004) Invertebrate zoology:

Editorial responsibility: Charles Birkeland,

Honolulu, Hawaii, USA a functional evolutionary approach. Brooks/Cole, Belmont, CA

Russ GR (2003) Grazer biomass correlates more strongly with production than with biomass of algal turfs on a coral reef. Coral Reefs 22:63-67

Sammarco P, Risk M, Schwarcz H, Heikoop J (1999) Crosscontinental shelf trends in coral $\delta^{15} \mathrm{~N}$ on the Great Barrier Reef: further consideration of the reef nutrient paradox. Mar Ecol Prog Ser 180:131-138

Shurin JB, Gruner DS, Hillebrand H (2006) All wet or dried up? Real differences between aquatic and terrestrial food webs. Proc R Soc Lond B Biol Sci 273:1-9

Spotte S (1998) 'Cleaner' shrimps? Helgol Meeresunters 52 $59-64$

Stella JS, Jones GP, Pratchett MS (2010) Variation in the structure of epifaunal invertebrate assemblages among coral hosts. Coral Reefs 29:957-973

Stella JS, Pratchett MS, Hutchings PA, Jones GP (2011) Coral-associated invertebrates: diversity, ecological importance and vulnerability to disturbance. Oceanogr Mar Biol Annu Rev 49:43-104

Takada Y, Abe O, Shibuno T (2007) Colonization patterns of mobile cryptic animals into interstices of coral rubble. Mar Ecol Prog Ser 343:35-44

Takada Y, Abe O, Shibuno T (2008) Cryptic assemblages in coral-rubble interstices along a terrestrial-sediment gradient. Coral Reefs 27:665-675

$>$ Taylor RB (1998) Density, biomass and productivity of animals in four subtidal rocky reef habitats: the importance of small mobile invertebrates. Mar Ecol Prog Ser 172: $37-51$

van Guelpen L, Markle DF, Duggan DJ (1982) An evaluation of accuracy, precision, and speed of several zooplankton subsampling techniques. J Cons Int Explor Mer 40: 226-236

Vetter EW (1995) Detritus-based patches of high secondary production in the nearshore benthos. Mar Ecol Prog Ser 120:251-262

Vroom PS (2011) 'Coral dominance': a dangerous ecosystem misnomer? J Mar Biol 2011:164127, doi:10.1155/2011/ 164127

Vytopil E, Willis BL (2001) Epifaunal community structure in Acropora spp. (Scleractinia) on the Great Barrier Reef: implications of coral morphology and habitat complexity. Coral Reefs 20:281-288

Submitted: May 15, 2014; Accepted: July 17, 2014

Proofs received from author(s): September 14, 2014 